\title{
WELCOME IN MARTINIQUE
}

Dear friends,

On behalf of the organizing committee, I am delighted to have the privilege to welcome you all to the 46th meeting of The International Association of Forensic Toxicologists (TIAFT). This is the first time that the French West Indies will host the most important annual event of our discipline. This meeting will offer a unique opportunity to share knowledge and experience with colleagues from all round the world, bringing together the vast expertise of scientists actively working in the various fields of Forensic Toxicology.

This event will be shared with 2 others scientific societies, the French Society of Analytical Toxicology (SFTA) and the Society of Hair Testing (SoHT). Both of these bodies are important for me, as I am actively engaged in their scientific developments. It is also a great opportunity to create a unique and original concept under the local sun, beach and palms.

To host in Martinique a large number of active participants and accompanying persons, the Organizing Committee has continually worked since 3 years. All of us have given their time, their ideas, their feelings and even sometimes their anxiety to make a complete success of the conference. Each of them was present to offer his input to build this 18 pieces puzzle of the local board. Beside the scientific program, we will offer you an exciting social program, guaranteed to leave you with fond memories of Martinique and to discover for the second time after Paris, the French touch. We hope we have designed events which you will not want to miss.

It is my sincere hope and belief that the meeting will be the right place to make new contacts, to nurture old ones or simply to meet others who share the same concerns.

In the hope that all our tireless efforts will correspond to your expectations, I, as well as the Organizing Committee, welcome you in Martinique.

Pascal Kintz, TIAFT President

For the first time, the French Society of Analytical Toxicology (SFTA) will have its annual congress jointly with the annual meetings of two international societies, the International Association of Forensic Toxicologists and the Society of Hair Testing. The SFTA couldn't expect a better opportunity for celebrating its $20^{\text {th }}$ anniversary and $16^{\text {th }}$ annual congress.

For the first time, the members of these three societies will be gathered one week long, a unique opportunity for the free and open exchange of ideas between colleagues about all the subjects that will determine the future of toxicology.

For the second time, a TIAFT meeting will take place in a French country and on behalf of the SFTA board, we are proud to welcome international colleagues again.

We have worked hard not just to ensure a professional and fruitful congress but also to provide all the participants with a pleasant, friendly and memorable visit in Martinique, a real paradise.

So... Enjoy your meeting in Martinique!

Patrick Mura, SFTA President

S1-II

Article available at http://www.ata-journal.org or http://dx.doi.org/10.1051/ata:2008014 
Dear colleagues and friends,

The Society of Hair Testing (SoHT) is delighted to continue with the tradition of the annual meetings, and to invite you to the 2008 SoHT Meeting in Martinique.

This year we will have the chance to share our meeting with two other associations involved in hair analysis, as well, The International Association of Forensic Toxicologists (TIAFT) and the French Society of Analytical Toxicology (SFTA). I thank both of them for giving us the opportunity of participating in this relevant event.

It is very important for SoHT to join TIAFT once again, because we originated from this Association. In fact, the first meeting on hair analysis, before SoHT's being set up, were organized by the TIAFT's President, at that time Dr. Rokus A. de Zeeuw. In addition, the majority of our members belong to TIAFT, as well, and actively participate in its events. This collaboration will be very interesting for TIAFT and SFTA members, since hair analysis is performed in the majority of the toxicological labs, and this is a good chance to know SoHT and to exchange ideas, opinions or doubts with people involved in the same field.

I am sure that Martinique will be unforgettable not only from the scientific, but also from the social point of view. It is a heavenly island and the organizing committee has been and continues working very hard for the success and for us to enjoy the place, the atmosphere and to recall this meeting as one of the best in our lives.

I hope and expect to see all of you in Martinique.

Carmen Jurado, SoHT President 